\title{
Indomethacin decreases viscosity of gallbladder bile in patients with cholesterol gallstone disease*
}

\author{
C. von Ritter ${ }^{1}$, A. Niemeyer ${ }^{1}$, V. Lange ${ }^{2}$, W. Möhrle ${ }^{1}$, W.O. Richter ${ }^{1}$, L. von Meyer ${ }^{3}$, H. Brandl ${ }^{1}$, \\ R. del Pozo ${ }^{1}$, D. Jüngst ${ }^{1}$ \\ ${ }^{1}$ Medizinische Klinik II, ${ }^{2}$ Chirurgische Klinik, ${ }^{3}$ Institut für Rechtsmedizin, Klinikum Großhadern, \\ Ludwig-Maximilians-Universität München
}

Summary. There is experimental evidence that inhibition of cyclooxygenase with nonsteroidal anti-inflammatory drugs may decrease cholesterol gallstone formation and mitigate biliary pain in gallstone patients. The mechanisms by which NSAIDs exert these effect are unclear. In a prospective, controlled clinical trial we examined the effects of oral indomethacin on the composition of human gallbladder bile. The study included 28 patients with symptomatic cholesterol or mixed gallstones. Of these, 8 were treated with $3 \times 25 \mathrm{mg}$ indomethacin daily for 7 days prior to elective cholecystectomy while 20 received no treatment and served as controls. Bile and tissue samples from the gallbladder were obtained during cholecystectomy. Indomethacin tissue levels in the gallbladder mucosa, as assessed by HPLC, were $1.05 \pm 0.4 \mathrm{ng} / \mathrm{mg}$ wet weight, a concentration known to inhibit effectively cyclooxygenase activity. Nevertheless, no differences between the treated and untreated groups were found in the concentrations of biliary mucus glycoprotein $(0.94 \pm 0.27$ versus $0.93 \pm 0.32 \mathrm{mg} / \mathrm{ml})$ or total protein $(5.8 \pm 0.9$ versus $6.4 \pm 1.3 \mathrm{mg} / \mathrm{ml})$, cholesterol saturation $(1.3 \pm 0.2$ versus $1.5 \pm 0.2)$, or nucleation time $(2.0 \pm 3.0$ versus $1.5 \pm 2.0$ days $)$. However, biliary viscosity, measured using a lowshear rotation viscosimeter, was significantly lower in patients receiving indomethacin treatment $(2.9 \pm 0.6$ versus $5.6 \pm 1.2 \mathrm{mPa} . \mathrm{s} ; P<0.02)$. In conclusion, in man oral indomethacin decreases bile viscosity without alteration of bile lithogenicity or biliary mucus glycoprotein content. Since mucus glycoproteins are major determinants of bile viscosity, an alteration in mucin macromolecular composition may conceivably cause the indomethacin-induced decrease in biliary viscosity and explain the beneficial effects of nonsteroidal anti-inflammatory drugs in gallstone disease.

Abbreviation: NSAIDs $=$ nonsteriodal anti-inflammatory drugs

* Dedicated to Prof. Dr. G. Paumgartner on the occasion of his 60th birthday
Key words: Biliary mucus - Nonsteroidal anti-inflammatory drugs - Cholesterol nucleation time

In animal models of cholesterol gallstone disease nonsteroidal anti-inflammatory drugs (NSAIDs) decrease the tendency of bile to form gallstones [10]. The mechanisms responsible for this effect of NSAIDs are unclear. Inhibition of mucus secretion has been proposed as a potential mode of action. This view is based on the observation that in a number of animal models mucus hypersecretion is observed before crystal formation [11], and that in the prairie dog aspirin inhibits both cholesterol crystal formation and mucus secretion [10]. Recent studies on prairie dog gallbladder explants [15], however, failed to show an effect of aspirin on mucus secretion in concentrations which effectively inhibit prostaglandin synthesis. Furthermore, the relevance of the data collected in animal experiments for cholesterol gallstone disease in man is unclear. Studies in gallstone patients suggest that under aspirin treatment gallstone formation is reduced both during weight loss [2] and after successful litholytic therapy [7]. A recent prospective study by Rhodes et al [16] showed that in gallstone patients aspirin decreases mucus synthesis without a reduction in the mucus concentration of bile.

The present study was designed to define the effect of oral indomethacin on lithogenicity of bile in patients with cholesterol gallstone disease. To seek a better understanding of the mechanisms involved in the action of NSAIDs in gallstone disease a detailed analysis of bile was performed, including measurement of biliary lipids, proteins, mucus glycoproteins, and viscosity. Finally, to determine whether indomethacin treatment is sufficient to achieve effective drug levels in the tissue, indomethacin tissue concentrations were measured in the gallbladder mucosa. These measurements also served as index for patient compliance. 


\section{Material and methods}

\section{Experimental design and patients}

The study was designed as a prospective, controlled clinical trial. Twenty-eight patients were studied. Exclusion criteria were acute cholecystitis with obstruction of the cystic duct, gastroduodenal ulcera, or hypersensitivity to indomethacin. Twenty patients received no treatment and served as controls. Eight gave informed consent to be treated with indomethacin $25 \mathrm{mg}$ three times daily for 7 days prior to cholecystectomy and finished the full course of the 7-day treatment. Age, sex, number of gallstones and cholesterol content of gallstones of the patients in both groups are listed in Table 1.

\section{Collection of samples}

Bile was collected during cholecystectomy by complete aspiration of gallbladder bile with a $16-\mathrm{G}$ needle. Aspiration was performed immediately after ligation of the cystic duct. Samples were kept under anaerobic conditions and processed within $30 \mathrm{~min}$ after aspiration. Aspirates contaminated with blood were not used. From the corpus of the gallbladder $2 \times 1 \times \mathrm{cm}$ tissue samples were taken, frozen in liquid nitrogen and stored at $-30^{\circ} \mathrm{C}$.

\section{Indomethacin tissue levels}

To determine compliance and to control for interindividual differences in the absorption of indomethacin into the gallbladder mucosa, indomethacin tissue levels were measured in homogenized samples of the gallbladder mucosa using HPLC in a modified method as described by Shankar et al 1988 [18]. Briefly, samples of the gallbladder wall $\left(2 \mathrm{~cm}^{2}\right)$ obtained during cholecystectomy were dissected sharply into the mucosal and muscular layer. The mucosa was homogenized using an Ultra Turrax T25 Homogenizer diluted with phosphate buffer and incubated for $2 \mathrm{~h}$ in a papain, cysteic acid, and EDTA solution to ensure complete release of indomethacin from the tissue matrix. The samples were centrifuged at $12000 \mathrm{rpm}$ for $5 \mathrm{~min}$. The supernatant was extracted using $2 \mathrm{ml}$ diethyl ether and the organic layer evaporated to dryness in a $60^{\circ} \mathrm{C}$ waterbath. The dried extract was reconstituted in $30 \mu \mathrm{l}$ acetonitrile $/ \mathrm{H}_{2} \mathrm{O}(1: 1)$ solution and a $20 \mu \mathrm{l}$ aliquot of this solution was injected in the HPLC. A Beckmann (model 340 organizer) HPLC equipped with a Beckmann solvent delivery module (model 112) variable wavelength detector
Table 1. Characteristics of patients

\begin{tabular}{lll} 
& Untreated & $\begin{array}{l}\text { Indomethacin } \\
\text { treated } \\
(n=8)\end{array}$ \\
\hline $\begin{array}{l}\text { Mean age } \\
\text { (years; range) }\end{array}$ & $48(23-71)$ & $49(29-69)$ \\
$\begin{array}{l}\text { Sex (female/male) } \\
\begin{array}{l}\text { Number of stones } \\
\text { (solitary/multiple) }\end{array}\end{array}$ & $15 / 5$ & $8 / 0$ \\
$\begin{array}{l}\text { Cholesterol content } \\
\text { of stone(s) }(\%)\end{array}$ & $58 \pm 8$ & $5 / 3$ \\
\hline
\end{tabular}

(model 165) and a Merck-Hitachi Chromato-integrator (model D 2500) was used. The analytical column was a Merck LiChrospher 60, RP-select B. Column temperature was $22^{\circ} \mathrm{C}$ and the flow rate $0.8 \mathrm{ml} / \mathrm{min}$. For drug detection the column eluate was measured at $254 \mathrm{~nm}$. Sensitivity and linearity were tested with standard solutions of indomethacin $(0.1,0.5,1.0,2.0,5.0 \mathrm{ng} / \mathrm{ml})$ disolved in methanol. Mefenamin $(50 \mu \mathrm{l})$ was used as internal standard. Recovery was calculated by comparison of standard solutions added to drug-free tissue samples and standard solutions in methanol.

\section{Analysis of bile}

Nucleation time was determined as described by Holan [6]. For the analysis of biliary lipids samples were stored at $-70^{\circ} \mathrm{C}$. Cholesterol was determined colorimetrically with the Liebermann-Burchard reaction [1]. Phospholipids were measured as total biliary phosphate using the colorimetric assay of Fiske and Subbarow [4]. Total bile salts were determined by a modified $3 \alpha$-hydroxysteroid dehydrogenase method [20]. The cholesterol saturation index of each sample was calculated according to Carey [3]. Total proteins were determined using a modified Lowry assay according to Jüngst et al. [8]. The $\mathrm{pH}$ values were determined immediately after aspiration in bile samples kept under anearobic conditions.

Mucus glycoproteins were separated from bile by gel permeation chromatography. Sepharose $2 B-$ CL columns $(80 \times 2.5 \mathrm{~cm})$ were loaded with $1 \mathrm{ml}$ samples of bile and eluted with $0.2 \mathrm{M} \mathrm{NaCl}$ containing $0.03 \%$ sodium azide $\left(\mathrm{NaN}_{3}\right)$. Void volume was determined with blue dextran 2000. Mucin was quantitated in the void volume using the modified periodic acid-Schiff assay described by Mantle and Allen [13] with pig gastric mucin serving as standard. 


\section{Bile viscosity}

Viscosity of gallbladder bile was determined as dynamic viscosity using a Low Shear Rotation Viscosimeter (Contraves, Zurich, Switzerland). The rotation viscosimeter allows accurate measurements of viscosity of both newtonian and nonnewtonian fluids. Dynamic viscosity was calculated from the shear forces exerted by a fluid placed in a rotating outer cylinder $(2 \mathrm{~T} ; 12 \mathrm{~mm}$ diameter $\times 11 \mathrm{~mm}$ height); shear forces were measured with an inner cylinder $(2 \mathrm{~T} ; 11 \mathrm{~mm}$ diameter). The applied shear rate in our experiments was in a range between 10 and $118 / \mathrm{s}$. In all samples the viscosity curve reached a plateau at $60 / \mathrm{s}$. Viscosity was calculated from triple measurements at this plateau and expressed as millipascals times second (mPa.s).

\section{Statistical analysis}

Values of each group of parametric data are presented as mean \pm SEM. Non-parametric data (nucleation time) are expressed as median and range. Group comparison was performed for parametric data using unpaired Student's $t$ test and for nonparametric data using the Mann-Whitney $U$ test. The level of significance was set at $P<0.05$.

\section{Results}

Indomethacin tissue levels

A close linear detector response curve was found for indomethacin solutions in a range of $0.1-5 \mathrm{ng} /$ $\mathrm{ml}$. Recovery rates after extraction from drug-free mucosal homogenates were $94 \%$. Duplicate analyses varied less than 5\%. No indomethacin was measured in the gallbladder mucosa of untreated patients. In the treated group indomethacin tissue levels were $1.05 \pm 0.4 \mathrm{ng} / \mathrm{mg}$ wet weight.

\section{Analysis of bile}

Despite these significant differences in indomethacin tissue concentrations no significant differences were found in $\mathrm{pH}$, biliary lipids, or total protein content of bile (Table 2). Lithogenicity of bile, as determined by nucleation time, was also unaltered by indomethacin treatment. Furthermore, indomethacin failed to decrease biliary mucus glycoprotein content. However, as shown in Fig. 1 dynamic viscosity was significantly decreased in patients receiving indomethacin treatment.
Table 2. Effect of indomethacin on biliary lipids, total proteins, mucin glycoproteins, $\mathrm{pH}$, and nucleation time

\begin{tabular}{lcc}
\hline & $\begin{array}{l}\text { Untreated } \\
(n=20)\end{array}$ & $\begin{array}{l}\text { Indomethacin } \\
(n=8)\end{array}$ \\
\hline $\begin{array}{l}\text { Nucleation time } \\
\text { median (range) }\end{array}$ & $2(1-4)$ & $2(1-14)$ \\
pH & $7.5 \pm 0.1$ & $7.4 \pm 0.1$ \\
$\begin{array}{l}\text { Cholesterol } \\
\text { (mmol/l) }\end{array}$ & $21.5 \pm 5.8$ & $16.8 \pm 5.6$ \\
$\begin{array}{l}\text { Bile acids } \\
\text { (mmol/1) }\end{array}$ & $139.8 \pm 20.0$ & $107.9 \pm 22.1$ \\
$\begin{array}{l}\text { Phospholipids } \\
\text { (mmol/l) }\end{array}$ & $43.0 \pm 5.8$ & $38.4 \pm 6.9$ \\
$\begin{array}{l}\text { Total lipids } \\
\text { (g/dl) }\end{array}$ & $10.98 \pm 1.46$ & $9.5 \pm 1.77$ \\
$\begin{array}{l}\text { Cholesterol } \\
\text { saturation index }\end{array}$ & $1.29 \pm 0.23$ & $1.51 \pm 0.18$ \\
$\begin{array}{l}\text { Total proteins } \\
\text { (mg/ml) }\end{array}$ & $5.7 \pm 0.9$ & $5.9 \pm 0.9$ \\
$\begin{array}{l}\text { Mucus glycoproteins } \\
(\mu \mathrm{g} / \mathrm{ml})\end{array}$ & $0.81 \pm 0.22$ & $0.95 \pm 0.27$ \\
\hline
\end{tabular}

No significant alterations were observed in response to indomethacin

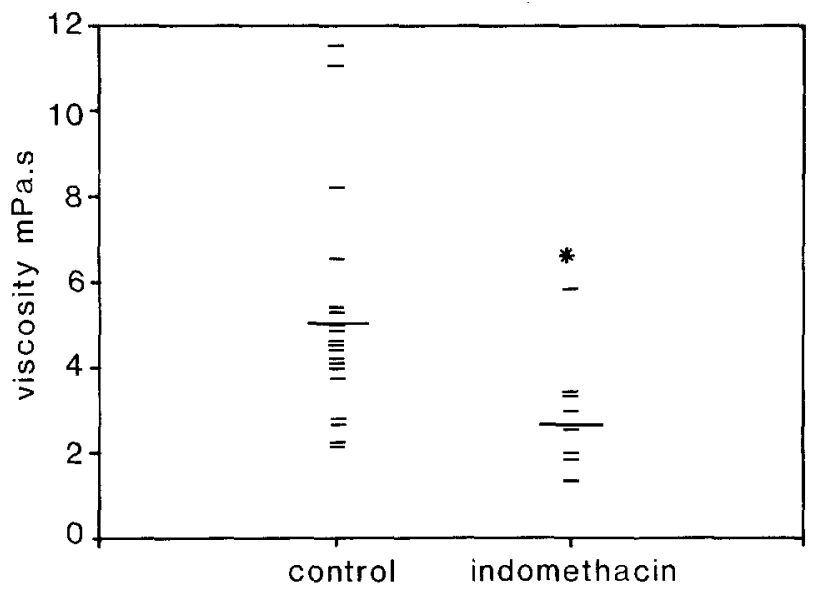

Fig. 1. Effect of indomethacin on bile viscosity. Indomethacin induced a significant decrease in dynamic viscosity $(P<0.05)$

\section{Discussion}

Indomethacin is a NSAID which inhibits prostaglandin synthesis. We measured indomethacin tissue levels in gallbladder mucosa homogenates in patients treated with $75 \mathrm{mg} /$ day for 7 days. The tissue levels were $1.05 \pm 0.4 \mathrm{ng} / \mathrm{mg}$ wet weight, a concentration known to inhibit effectively the enzymatic activity of prostaglandin synthetase $[5,15]$. The data collected in this study show that this inhibition of prostaglandin synthesis in pa- 
tients with cholesterol gallstone disease leaves nucleation time, biliary lipids, cholesterol saturation, and proteins unchanged (Table 2). Biliary mucus hypersecretion precedes cholesterol crystal formation in the prairie dog [11]; in this animal high doses of aspirin prevent both mucus hypersecretion and cholesterol crystal formation [10]. It has therefore been speculated that aspirin may prevent gallstone formation by inhibition of mucus secretion. However, in our study, as observed previously in both prairie dogs [15] and man [16], indomethacin failed to decrease biliary mucus glycoprotein content. Therefore, other mechanisms appear to be responsible for the beneficial effects of cyclooxygenase inhibitors in gallstone disease.

A major finding of our study is the observation that indomethacin decreases the viscosity of gallbladder bile. Bile viscosity may play an important role in the formation of cholesterol crystals in human bile. Since bile flux through the cystic duct is inversely correlated to bile viscosity (Poiseuille's law), increases in bile viscosity may decrease the emptying of the gallbladder, thereby allowing cholesterol crystal growth. Recently indomethacin has been found to enhance postprandial emptying of the gallbladder in patients with cholesterol gallstone disease; indomethacin had no effect on gallbladder motility of healthy volunteers [14]. It is tempting to speculate that the indomethacin-induced decrease in bile viscosity observed in our study is the mechanism allowing improved gallbladder emptying. Further studies are needed to better define the correlation between gallbladder motility and bile viscosity.

Mucus glycoproteins are major determinants of bile viscosity. However, the data of the present study indicate that indomethacin decreases bile viscosity without changing biliary mucus glycoprotein content. One possibility to explain this apparent discrepancy is that indomethacin alters the oligomeric structure of the mucus molecule. The correlation between bile viscosity and alterations in the biliary mucus macromolecule has been carefully studied by Smith and coworkers [19]. Apparent viscosity and the size of the mucin polymer were found to be strongly dependent on $\mathrm{pH}$, with a maximum of viscosity at $\mathrm{pH}$ 5.5. Our study showed no differences in $\mathrm{pH}$ in response to indomethacin. This makes it unlikely that differences in the degree of protonation account for the changes in viscosity observed. Studies of intestinal mucus synthesis [9] have shown that inhibition of cyclooxygenase with aspirin affects glycoprotein synthesis by at least two separate mechanisms: firstly, by reduced synthesis of peptides and, secondly, by reduced oligosaccharide assembly of the mucus glycoproteins. Aspirin appears to inhibit specifically acetylation of glucosamines [12]. Similar to these findings, aspirin-induced inhibition of mucus synthesis has also been observed in human gallbladder explants in two recent studies by Rhodes et al $[16,17]$. Taken together, there is experimental evidence showing that NSAIDs may interfere with mucin synthesis, possibly altering the degree of mucin glycosylation. Further studies are needed to clarify the effects of NSAIDs on the composition and structure of biliary mucins.

Acknowledgements. Part of the study was presented at the annual meeting of the American Gastroenterological Association, San Fransisco, 1992. The study was supported by grants from the Deutsche Forschungsgemeinschaft [Ri 584/1-1] and the Friedrich-Baur-Stiftung [74/91;57/89]. The technical assistance of Benedikta Zündt and Carsten Meinecke is gratefully acknowledged.

\section{References}

1. Abell LL, Levy BB, Brodie BB, Kendall FE (1952) A simplified method for the estimation of total cholesterol in serum and demonstration of its specificity. J Biol Chem 195:357366

2. Broomfield PH, Chopra R, Sheinbaum RC, Bonorris GG, Silverman A, Schoenfield LJ, Marks JW (1988) Effects of ursodeoxycholic acid and aspirin on the formation of lithogenic bile and gallstones during loss of weight. New Engl J Med 319:1567-1572

3. Carey MC (1978) Critical table for calculation of the cholesterol saturation of native bile. J Lipid Res 19:945-955

4. Fiske CH, Subbarow Y (1925) The colorimetric determination of phosphorus. J Biol Chem 66:375-400

5. Flower RJ, Vane JR (1974) Inhibition of prostaglandin biosynthesis. Biochem Pharmacol 23:1439-1450

6. Holan KR (1979) Nucleation time: a key factor in the pathogenesis of cholesterol gallstone disease. Gastroenterology 77:611-617

7. Hood K, Gleeson D, Ruppin DC, Dowling RH (1988) Prevention of gallstone recurrence by non-steroidal anti-inflammatory drugs. Lancet II: 1223-1225

8. Jüngst D, Lang T, von Ritter C, Paumgartner G (1991) Role of high total protein in gallbladder bile in the formation of cholesterol gallstones. Gastroenterology 100:1724-1729

9. Kent PW, Allen A (1968) The biosynthesis of intestinal mucins: the effect of salicylate on glycoprotein biosynthesis by sheep colonic and human gastric mucosal tissues in vitro. Biochem J 106:645-658

10. Lee SP, Carey MC, LaMont JT (1981) Aspirin prevention of cholesterol gallstone formation in prairie dogs. Science 211:1429-1431

11. Lee SP, LaMont JT, Carey MC (1981) Role of gallbladder mucus hypersecretion in the evolution of cholesterol gallstones: Studies in prairie dog. J Clin Invest 67:1712-1723

12. Lukie BE, Forstner GG (1972) Synthesis of intestinal clycoproteins: inhibition of $\left(\mathrm{I}-\mathrm{C}^{14}\right)$ glucosamine incorporation by sodium salicylate in vitro. Biochim Biophys Acta 273:380388

13. Mantle M, Allen A (1978) A colorimetric assay for glycoproteins based on the periodic acid/Schiff stain. Biochem Soc Trans 6:607-609 
14. O'Donnell LJD, Wilson P, Guest P, Catnach SM, McLean A, Wickham JEA, Fairclough PD (1992) Indomethacin and postprandial gallbladder emptying. Lancet 339:269-271

15. O'Leary DP, LaMorte WW, Scott TE, Booker ML, Stevenson $J$ (1991) Inhibition of prostaglandin synthesis fails to prevent gallbladder mucin hypersecretion in the cholesterolfed prairie dog. Gastroenterology 101:812-820

16. Rhodes M, Allen A, Dowling RH, Murphy G, Lennard TWJ (1992) Inhibition of human gall bladder mucus synthesis in patients undergoing cholecystectomy. Gut 33:1113-1117

17. Rhodes M, Allen A, Lennard TWJ (1992) Mucus glycoprotein biosynthesis in the human gall bladder: inhibition by aspirin. Gut 33:1109-1112

18. Shankar V, Damodaran C, Sekharan PC (1988) Isolation of alkaloids and glycosides from tissue following enzymic digestion. Forensic Sci Int 37:243-248
19. Smith BF, Peetermans JA, Tanaka T, LaMont JT (1989) Subunit interactions and physical properties of bovine gallbladder mucin. Gastroenterology 97:179-187

20. Talalay P (1960) Enzymatic analysis of steroid hormones. Biochem Anal 8:119-143

Received: May 3, 1993

Returned for revision: July 5, 1993

Accepted: July 9, 1993

Dr. C. von Ritter

Medizinische Klinik II

Klinikum Großhadern

Marchioninistraße 15

D-81366 München, Germany 